\title{
GUIDE TO EDITORIAL APPARATUS
}

[roman]

[italic]

$\langle$ roman〉

$\langle$ italic $\rangle$

SMALL CAPITALS
TEXTUAL DEVICES

Conjectural reading for missing or illegible matter (a question mark follows when the reading is doubtful); interpolated explanation of gallicisms; matter taken from another copy or added to the manuscript. See notes for each document.

Editorial comment inserted in the text.

Matter deleted in the manuscript, or in Lafayette, Mémoires, but here restored. See provenance note for each document.

Docketing or marginal reply to issues raised in the document.

Matter written in cipher and deciphered interlinearly.

DESCRIPTIVE SYMBOLS

AD Autograph document

ADS Autograph document signed

AL Autograph letter

ALS Autograph letter signed

AM Autograph manuscript

AMS Autograph manuscript signed

D Document

DS Document signed

E Extract

ET Extract, translation

L Letter

LbC Letter-book copy

LS Letter signed

M Manuscript

$\mathrm{T}$ Translation

\section{LOCATION SYMBOLS}

American repositories (with abbreviations as in the National Union Catalogue of the Library of Congress): 
CSmH Henry E. Huntington Library and Art Gallery, San Marino, California

CSt Manuscripts Division, Department of Special Collections, C. H. Green Library, Stanford University, Stanford, California

Ct Connecticut State Library, Hartford

CtHi Connecticut Historical Society, Hartford

CtY Yale University Library, New Haven, Connecticut

DLC Manuscript Division, Library of Congress, Washington, D.C.

DNA National Archives and Records Service, Washington, D.C.

ICU Department of Special Collections, Joseph Regenstein Library, University of Chicago

InU Lilly Library, Indiana University, Bloomington

MH Houghton Library, Harvard University, Cambridge, Massachusetts

MHi Massachusetts Historical Society, Boston

MdAA State of Maryland, Department of General Services, Hall of Records, Annapolis

MdHi Museum and Library of Maryland History, Maryland Historical Society, Baltimore

MiU-C William L. Clements Library, University of Michigan, Ann Arbor

$\mathrm{MnHi}$ Division of Archives and Manuscripts, Minnesota Historical Society, St. Paul

MoSHi Missouri Historical Society, St. Louis

NHi New-York Historical Society, New York

NIC Department of Rare Books, Cornell University Libraries, Ithaca, New York

NN Manuscripts and Archives Division, New York Public Library; Astor, Lenox, and Tilden Foundations, New York

NNC Rare Book Room and Manuscript Library, Columbia University Library, New York

NNPM Pierpont Morgan Library, New York

NhHi New Hampshire Historical Society, Concord

$\mathrm{NjHi} \quad$ New Jersey Historical Society, Newark

NjMoHP Morristown National Historical Park, Morristown, New Jersey

NjP Princeton University Library, Princeton, New Jersey

OClWHi Western Reserve Historical Society, Cleveland, Ohio

PEL David Bishop Skillman Library, Lafayette College, Easton, Pennsylvania

PHarH Pennsylvania Historical and Museum Commission, Harrisburg

PHi Historical Society of Pennsylvania, Philadelphia

PPAmP American Philosophical Society Library, Philadelphia

PWCS West Chester State College Library, West Chester, Pennsylvania

RHi Rhode Island Historical Society Library, Providence

RPAB Annmary Brown Memorial, Brown University, Providence

ScHi South Carolina Historical Society, Charleston

Vi Virginia State Library, Archives Branch, Richmond

ViU Manuscripts Department, Alderman Library, University of Virginia, Charlottesville 
Foreign repositories:

$\begin{array}{ll}\text { AAE } & \text { Archives du Ministère des Affaires Etrangères, Paris } \\ \text { ALG } & \text { Archives du Château de La Grange, Courpalay } \\ \text { AN } & \text { Archives Nationales, Paris } \\ \text { BMH } & \text { Bibliothèque Municipale du Havre } \\ \text { PRO } & \text { Public Record Office, London } \\ \text { SHA } & \text { Service Historique de l'Armée, Château de Vincennes }\end{array}$

\section{SHORT TITLES}

AHR: American Historical Review.

Archives of Maryland: Archives of Maryland, 70 vols. to date (Baltimore: Maryland Historical Society, 1883-).

Blanchard, Journal: Claude Blanchard, Guerre d'Amérique, I780-I 783 , journal de campagne, ed. Maurice La Chesnais (Paris, 1881).

Boyd, Jefferson Papers: Julian P. Boyd et al., eds., The Papers of Thomas Jefferson, 19 vols. to date (Princeton: Princeton University Press, 1950-).

Burnett, Letters of Congress: Edmund C. Burnett, ed., Letters of the Members of the Continental Congress, 8 vols. (Washington, D.C.: Carnegie Institution of Washington, 1921-1936).

Chastellux, Travels: François-Jean de Beauvoir, Chevalier de Chastellux, Travels in North America in the Years 1780,1781 , and I782, trans. Howard C. Rice, Jr., 2 vols. (Chapel Hill: University of North Carolina Press, 1963).

Clinton, American Rebellion: William B. Willcox, ed., The American Rebellion: Sir Henry Clinton's Narrative of His Campaigns, I 775-I 782 (New Haven: Yale University Press, 1954).

Clowes, Royal Navy History: Sir William Laird Clowes, The Royal Navy: A History from the Earliest Times to the Present, 7 vols. (London, 1897-1903).

Cushing, Writings of Samuel Adams: Harry Alonzo Cushing, ed., The Writings of Samuel Adams, 4 vols. (New York, 1904-19o8).

Doniol, Histoire: Jean-Henri Doniol, Histoire de la participation de la France à l'établissement des Etats-Unis d'Amérique, 5 vols. (Paris, 1884-1892).

Encyclopédie méthodique: Encyclopédie méthodique, ou par ordre de matières; par une société de gens de lettres..., 185 vols. (Paris, 1782-1832).

Fitzpatrick, Writings of Washington: John C. Fitzpatrick, ed., The Writings of George Washington, 39 vols. (Washington, D.C.: U.S. Government Printing Office, 1931-1944).

Gottschalk, Close: Louis Gottschalk, Lafayette and the Close of the American Revolution (Chicago: University of Chicago Press, 1942).

Gottschalk, Letters of Lafayette: Louis Gottschalk, ed., The Letters of Lafayette to Washington, I 777-I 779, rev. ed. (Philadelphia: American Philosophical Society, 1976).

Heath, Memoirs: William Abbott, ed., Memoirs of Major-General William Heath (New York, 1901).

Heath Papers: "Heath Papers," Collections of the Massachusetts Historical Society, 7 th ser., 5 (1905). 
Henry Lee, Memoirs: Henry Lee, Memoirs of the War in the Southern Department of the United States, ed. Robert E. Lee (New York, 1869).

JCC: Worthington C. Ford, ed., Journals of the Continental Congress, I 774-r 789, 34 vols. (Washington, D.C.: U.S. Government Printing Office, 1904-1937).

LAAR: Stanley J. Idzerda et al., eds., Lafayette in the Age of the American Revolution: Selected Letters and Papers, I776-1 79o, 3 vols. to date (Ithaca and London: Cornell University Press, 1977-).

Lafayette, Mémoires: Mémoires, correspondance et manuscrits du Général Lafayette, publiées par sa famille, 6 vols. (Paris, $1837-1838$ ). Letters written in English are translated into French.

Lopez, "Franklin and the Lafayette": Claude A. Lopez, "Franklin, Lafayette, and the Lafayette," Proceedings of the American Philosophical Society, 108, no. 3 (1964): $181-223$.

McGrady, South Carolina in the Revolution: Edward McGrady, The History of South Carolina in the Revolution, I775-I 780 (New York, 1902).

Madison Papers: William T. Hutchinson et al., eds., The Papers of James Madison, 10 vols. to date (Chicago: University of Chicago Press, 1962-).

MHS Proceedings: Proceedings of the Massachusetts Historical Society.

Patou, Lettres au Vicomte de Noailles: Jean Patou, ed., Lettres inédites du Général de La Fayette au Vicomte de Noailles... ( $1780-178 I)$ (Paris: Jean Patou, 1924).

Rice and Brown, Rochambeau's Army: Howard C. Rice, Jr., and Anne S. K. Brown, trans. and eds., The American Campaigns of Rochambeau's Army, ${ }_{7} 780$, $I 781,1782,1783,2$ vols. (Princeton: Princeton University Press; and Providence: Brown University Press, 1972).

St. Clair Papers: William Henry Smith, ed., The St. Clair Papers: The Life and Public Services of Arthur St. Clair, Soldier of the Revolutionary War, President of the Continental Congress, and Governor of the North-Western Territory, 2 vols. (Cincinnati, 1882).

Scharf and Westcott, History of Philadelphia: J. Thomas Scharf and Thompson Westcott, History of Philadelphia, I609-1 884, 3 vols. (Philadelphia, 1884).

Sibley, Harvard Graduates: John Langdon Sibley and Clifford K. Shipton, Sibley's Harvard Graduates: Biographical Sketches of Those Who Attended Harvard College ..., 17 vols. (Boston, 1873-1975).

Smyth, Writings of Franklin: Albert Henry Smyth, ed., The Writings of Benjamin Franklin, 10 vols. (New York and London, 1905-1907).

Syrett, Hamilton Papers: Harold C. Syrett et al., eds., The Papers of Alexander Hamilton, 26 vols. (New York and London: Columbia University Press, 1961-1979).

Van Doren, Secret History: Carl Van Doren, Secret History of the American Revolution (Garden City, N.Y.: Garden City Publishing Company, 1941).

Virginia Council Journals: H. R. McIlwaine et al., eds., Journals of the Council of the State of Virginia, 4 vols. to date (Richmond: Virginia State Library, 1931-).

Wharton, Diplomatic Correspondence: Francis Wharton, ed., The Revolutionary Diplomatic Correspondence of the United States, 6 vols. (Washington, D.C., 1889). 